AWEJ for translation \& Literacy Studies Volume, 1 Number 3, August 2017

DOI: http://dx.doi.org/10.24093/awejtls/vol1no3.10

Pp.139-161

\title{
The Use of Tautology in "The Thorn" by William Wordsworth: A Stylistic Study
}

\author{
Nawar Hussein Rdhaiwi Al-Marsumi \\ English Department, College of Languages, \\ Baghdad University, Baghdad, Iraq
}

\begin{abstract}
A tautology is to say the same thing twice where part of the sentence is redundant. The words are used and then expanded further in a way as if it has never been spoken before. It is the repetition or duplication of words; however; it has been argued that every repetition is not a tautology. Poets use this part of speech in their work for many years. Owing to its principal use in poems, it deserves an investigatory research work. This study aims at analyzing 'tautologies' in William Wordsworth's poem "The Thorn" from the viewpoint of stylistic analysis. This analysis can show the significance of the use of tautological words to conclude whether tautologies produce redundancy or make a poem beautiful. Leech (1969) is the model adopted in analyzing the selected poem where the concept of "Foregrounding" is introduced as being considered an important field of stylistic analysis. The analysis is quantitative where a statistical analysis is conducted. It is hypothesized that tautology is redundancy, whereas the findings reveal it as an expression of the depth of the human feelings. Wordsworth has successfully used tautology to achieve the themes included in his poem. This paper is hoped to help researchers know the position and effectiveness of tautology in literary texts, specifically, in poems.

Keywords: Duplication, foregrounding, redundancy, repetition, stylistic analysis, tautology
\end{abstract}

Cite as: Al-Marsumi, N.H. R. (2017). The Use of Tautology in "The Thorn" by William Wordsworth: A Stylistic Study. Arab World English Journal for Translation \& Literary Studies, 1(3).

DOI: http://dx.doi.org/10.24093/awejtls/vol1no3.10 


\section{Literature Review}

Style in fiction is a landmark study by Leech and Short (1981) in which they attempt to take into account the process, suggesting the relative transparency or opacity of the literary concept phenomenon in an metafunction approach. Leech and Short (1981) also try to address the fact that the literary or the poetic texts have several levels of linguistic style transparency. According to them the dualism of language has several means of passing in the same substance. On the other hand, the monism believes that using different words to convey the same message is a mistake and that any modification of language or the form of poetic brings a change in the content (Leech, 1969).

The authors propose that the dualists believe that every text can easily be paraphrased. According to Leech and Short (1981), the likeliness of paraphrasing is not challenged in the daily use language. However, in literature, the practice of paraphrasing becomes involved. To resolve this conflict, they argue about the analysis of the literary language in regards to its function or the metafunctions along with the poetic function of foregrounding.

The theories and concepts in the above- mentioned paragraphs do not only present the outline that is to follow but at the same time, they shed light on the reason behind the occurrence of the various phenomenon. Accordingly, it is necessary to provide grounds for the presence of these matters and at the same time, assist in looking for methods and ways for issues to be done effectively.

To analyze the complex phenomena of a language, analysts usually take into account the different elements that compose separately: the study of sounds (phonetics), the study of the lexicon (morphology) and the study of phrases and periods (syntax). In the use of real language, however, the linguistic behaviour does not occur in the form of sounds, words, phrases and clauses, but rather of a weave organic, characterized in that the elements that compose it are structured in a particular way. This intertwining of such elements is called linguistic analysis.

Lyricists and poets have been using an array of literary devices in their written pieces for many centuries. These devices may include metaphors, imagery, symbols, etc. Similarly, poets also use tautologies in writing down their masterpieces. This is indicated in one of the essential figures of speech in English literature. Therefore, it is significant to know the use of this part of the language.

Tautology is the repetition and is the redundant use of words that convey the same idea again and again in different words. It is either used to deliver the same message or to emphasize over an idea that has been presented just before (Pomorska, 1987). This repetition of words was common in the poems written by poets of 18th and 19th centuries. Establishing formal theories for the evaluation and hypothesizing of the regular repetition of words in the text can investigate the issue of tautology. It is noted that most of the tautologies in poems are overwhelmed by the uncertainty of the descriptive categories along with the related concepts, resulting in the methodological errors.

Tautology is also said to be expressions that elaborate something that has been already illustrated in the phrase before (Gibbs, 1994). According to Leech (1969), tautologies tell us nothing about the world and the language. The establishment of the more formal theories for 
evaluation and hypothesizing of the use of redundancy in poems might present a right solution of tautologies (Ward \& Hirschberg, 1991). However, these theories are still in the infant stage and are also weigh down by the complications of related concepts with the descriptive categories along with the critical differences between the two that is completely ignored and result in a methodological error.

Although, it sounds that tautology is only the repetition of words, arising from the reiteration of the same words; it is different from the replication or the redundancy arranged from the paraphrastic use of different words having the same meanings (Waldoff, 2001).Owing to these facts, tautology raises the bar of poems, and it is much more necessary than it appears at a glance. It is also linked to the operation of meaning in language. When different words are used to deliver the same meaning, it is suggested that meanings of those phrases or lyrics exceed the expressive powers of those words (Keach, 2004). Meanings of poetic words cannot be completely worn out by only the repetition, but it continues beyond them. Looking at this way, tautology seems to happen when language runs up against its figurative restrictions. However, it is interesting to note that tautology does not only identify the limitations of language but also marks the very potential of transcending those limitations.

There are many reasons which make the repetition and tautology become the beauties for the poems. The most important reason is the interest that the mind of the reader attached to the words he/she reads. Words are no longer words or only symbols of passion they become attractive and active things that are also the part of the passion. This is a crucial point. The ambivalence of the poet in the poem as well as his note towards the repetition and tautology can be noticed. Initially, these are seen as the externalities of its form, language as different from the content of the poem (Sarker, 2003). However, the implicit licensing of a supposed style substance over the notwithstanding form affirms that there are various reasons why tautology and repetition are frequently used in Wordsworth poem. Tautology is not only a mindless repetition of words, but it is an expression of the depth of the human feelings (Russell, 2005).

Moore (2001) states that tautology is a faulty repetition of phrases, such as: 'me, myself and I.' Current definitions do not clarify repeated words or ideas and they leave it unclear. Three dictionary definitions may illustrate this confusion: the Concise Oxford Dictionary (2011) states: "the unnecessary repetition within a statement of the same thing in different words (P.1477)". The Merriam-Webster's Dictionary of Synonyms (1984) states: "Needless or useless repetition of the same an idea in different words (P.857)". And the Oxford Dictionary of English (2010) defines Tautology as: "the saying of the same thing twice over in different words; generally considered to be a fault of style (P.1822)". Moore (2001) adds that the following terms are related to tautology, showing that repetition comes in different forms:

1. Antanaclasis: The repetition of the same words in a different, if not a contrary signification, such as: that's that! or who's who.

2. Paronomasia: A play upon words in which the same word is used in different senses or words similar in sound are set in opposition so as to give antithetical force: Thou art Peter [rock], and upon this rock, I shall build my.(Moore, 2001)

3. Pleonasm: The Merriam-Webster's Dictionary of Synonyms (1984) states that pleonasm is best defined as "the use of syntactically unnecessary words as in "the man he said" (P.857)". 
4. Redundancy: the use of more words than are required by idiom or syntax and hence, regarded as a fault of style. (Merriam-Webster's Dictionary of Synonyms, 1984)

Functions of Tautological Constructions

Intended Vagueness:

Tautologies can be used to achieve ambiguity. Political demagoguery falls into this category. States (1989: 51-66) explains that tautology, strategically, would be a way of saying something without actually saying much. This strategy has a dominant element of populism: one cannot tautologize to an elite audience:

(1) "I am that I am ......"

(2) "I am the God who IS....."

\section{Acceptance/resignation}

Tautologies can be used to communicate the need to accept or resign oneself to something. In English, every type of tautology can be used with this function, as shown in:

(3) But war is war. It isn't pretty.

(4) An early day is an early day.

(5) ...either I'll find it or I won't, ...

\section{Denial of Difference within Category}

This type is used to deny the importance of differences between members of a category. It can sometimes be used to communicate that, for the present purposes, all members of a class are the same. (Bulhof \& Gimbel, 2001). Examples are found in equatives, conditionals, and disjunctions, as shown in:

(6) A win is a win ... Even if it's a weird one.

(7) If it's slow, it's slow.

(8) You do it or you don't.

\section{Inadequacies of Language}

Cherry (1978) states that this type arises out of "the inadequacies of language itself. This latter requires expanding phrases and sentences until we are content that we have 'conveyed our meaning.' Jespersen (1917), similarly, explains the use of the unnecessary double negation, stating that: "The insignificance of these elements makes it desirable to multiply them so as to prevent their being overlooked (P.72)":

(9) "We don't never let him get off the place."

(10) "It wasn't none of my cars; I tell you!".

\section{Obligation}

Such tautologies can be used to communicate that one must fulfill one's obligations. Examples can only be found in equatives. (Wierzbicka, 1987):

(11) A deal's a deal.

(12) A bet's a bet.

(13) The law's the law.

\section{Derision}


Tautology can be used with neither strengthening nor weakening, but rather rests on the ridicule inherent in it. The following is a quotation from Shakespeare (2002):

(14) "Polonius: What do you read, my lord? / Hamlet: Words, words, words (P.74)".

\section{Poetic Device}

Several types of tautology may appear with technical aspects of repetition can be used: imitation, ornamentation, and figures of speech. These are used in everyday language and as a poetic device. This example is taken from Eliot (2003):

(15) "This is the way the world ends/ This is the way the world ends/ This is the way the world ends/ Not with a bang but a whimper (P.108)"

\section{Linguistic and Poetic Language}

In the protocols of modern linguistics, the poetic language is a particular use of language designed to obtain evidence through communication and enhancement tools signifiers of the form (phonetic, syntactic, etc.) of words and speech. Jakobson (1960) writes that "the emphasis on the message for himself, is the poetic function of language (P 1-21)".

The poetic language as it stands has its rules of operation. Jakobson (Ibid) notices that when carrying out a phrase, you choose words that are similar between different ones. He clarifies that when talking about 'car' we can use (automobile, car, and machine), and when saying that it is set in motion, we can use (does not work, do not start, do not go, do not turn on, etc...). This theory is not only vital to analyze the language of poems in general but is also important when it comes to analyses of the use of tautologies in poems. It is because that linguistics in poems stresses upon the use of different words conveying same meanings.

Deviation from the norm, however, the prevalence or importance of the requirements of similarity between words in the succession of the same traits are characteristic of poetic language, that the literary language uses and enhances particularly. It is understood, however, that the properties of poetic language are more visible and operating in poetry and drama in verse, and more in lyric poetry than in the epic narrative, theater and more tragic than in the comic.

\section{Stylistic Analysis}

The term "anthropological linguistics" is, at best, redundant. If, as now allowed linguists, language is a specifically human phenomenon and linguistics studies precisely this phenomenon, meaningless adjectives that designate the term that way (Mitchell, 2013). Discussion on the new creation of new linguistic ideologies began in the third millennium with a tautology serves as a reminder that many statements about the language are simple and they need to go back to redo clarity.

Short (1996) defines Stylistics as "an approach to the analysis of (literary) texts using linguistic description (P.1)". It has its root in the formalistic school of literary criticism emerged in Russia early in the twentieth century. Sarker (2003) states that "the very existence of the word 'style' shows that something can be said about the words which does not refer directly to the content (P.258)". Verdonk (2002) defines stylistics as "the analysis of distinctive expression in language and the description of its purpose and effect (P.4)". Bradford (1997) says that stylistics is "an elusive and slippery topic every contribution to the vast multifaceted discipline of literary 
studies will involve an engagement with style (P.1)". However, with its objectivity, insights from linguistics and useful terminology, stylistics makes our interpretation valid and enhances our enjoyment of literature.

The stylistic analysis of a text can highlight the means implemented by a writer in a generic framework determined to share a specific worldview. It is generally based on the study of the style, for example, the study of vocabulary, figures of speech, syntax, etc. while balancing the form and substance (= meaning). The basis of stylistic analysis of a text is the belief that every literary text conveys a subjective vision, that is to say a non-neutral view. Thornborrow and Wareing (1998) limit some key aspects of stylistics as:

- Linguistics (the study of language) is to approach literary texts

- The discussion of texts according to objective criteria rather than according purely to subjective and impressionistic values

- Emphasis on the aesthetic properties of language (for example, the way rhyme can give pleasure)

\section{Model for Analysis}

The model adopted in analyzing the selected poem is drawn heavily on Leech (1969). Leech and Short (1981) distinguish four levels that describe the style of language. These levels are: semantics, syntax, phonology and graphology. While the semantic level is the level of meaning, syntax and phonology constitute what is often referred to as the "double articulation" of linguistic form: phonology being the "sound pattern" of the language (phonemes, stresses, rhythm and intonation), and syntax being, roughly speaking, "the abstract grammatical and lexical form of language". A fourth level is added by Leech and Short (1981) to suit the written medium of literature; it is the level of graphology.

Leech (1969) introduces the concept of "Foregrounding" considering it as an important field of stylistic analysis. Foregrounding as the major characteristic of stylistics is particularly useful in analyzing poetry. Two main types of foregrounding can be distinguished: Parallelism and Deviation. Whereas parallelism is unexpected regularity, deviation can be seen as unexpected irregularity. In fact, foregrounding is the core of stylistics and can be defined as a form of textual patterning which is motivated for literary aesthetic purpose. It is realized by linguistic deviation and linguistic parallelism (Simpson: 2007).

Leech (1969) says that there are different kinds of deviation found in poetry:

1. Lexical Deviation, when words deviate from their actual and standard form in order to have a deeper value in meaning and in aesthetics.

2. Semantic Deviation, when a word can have differences in meaning.

3. Phonological Deviation, this is the deviation in sound.

4. Morphological Deviation, this is the deviation in how a word is formed.

5. Grammatical Deviation, when poets disregard the rules of sentence. They sometimes put no period between sentences; make no space between words, also use the tenses incorrectly etc.

6. The Use of Dialect, when poems are written by those who want to express their emotions using features of socially or regionally defined dialects.

7. The Use of Register (a professional dialect). 
AWEJ for translation \& Literacy Studies Volume, 1 Number 3, August 2017

The Use of Tautology in "The Thorn" by William Wordsworth

Al-Marsumi

8. Historical Deviation when poets use archaic words to enhance the aesthetical value of the poem.

9. Graphological Deviation, when poets disregard the rules of writing.

Not all the above-mentioned deviations can be found in every poem. Poems may have one or more (Leech, 1969). Hence, some of these deviations will be the model in analyzing tautologies used in the selected poem. These may include (grammatical, morphological, graphological, and phonological) deviations.

The framework of Leech's (1969) model can be within the following steps:

1. Giving background about the poet and the poem.

2. Understanding the poem under analyzing.

3. Initiating a linguistic stylistic analysis within the levels of:

a. Lexis, by drawing a complete table to show the number and rate for each part of speech (content words) in the poem and to highlight the significance of their frequency in the poem. This also includes stating a lexical grouping for each lexical category to intemperate the relation of a particular repeated word with a series of conceptual groups in the poem.

b. Grammar, to concentrate on sentence types, types of clauses and phrases and tenses used in the poem and their influence on the context.

4. Investigating foregrounding within its primary components; deviation and parallelism.

\section{Wordsworth's Poetic Style}

William Wordsworth (1770-1850), son of John and Ann Cookson Wordsworth, was born in Cockermouth, Cumberland. He is one of the greatest poets in England and known as the poet of nature. His poems took on greater significance in English literature. His deep love for the "beauteous forms" of the natural world was established early. He had a belief that poetic style should be as simple and sincere as the language of everyday life and that the more the poet draws on elemental feelings and primal simplicities the better for his art. He advocated the use of simple language in poetry. Patra and Prasad (2006) state that Wordsworth continues to argue that poetry should be written in a language really used by humble and rustic men. He set himself to the task of freeing poetry from all its "conceits" and its "inane phraseology". He made certain very effective and striking experiments in the use of simple language.

Wordsworth was the first poet who fully recognised and deliberately practised the beauties of extreme simplicity; and this achievement constitutes his most obvious claim to fame. His use of the nobly-plain style has something unique and unmatchable.

William Wordsworth is also a poet who used tautology in his poems very frequently. Wordsworth's "The Thorn" (1798) is an example of such poem, in which tautologies have been used, without making it monotonous and dull (Side, 2006). "The Thorn" is said to be the piece which has used tautology at its best. In order to analyze the use of tautology in this poem, it is important to briefly know the context of the poem.

The Thorn Analysis

Supposedly born out of William Wordsworth's observation of a thorny, gnarled tree one stormy day in March 1798, "The Thorn" was first published in September that year as a contribution to 
his and Samuel Taylor Coleridge's landmark poetry collection Lyrical Ballads. The lyrical ballad is a collaboration of two great poets namely William Wordsworth and Samuel Taylor Coleridge. It was first published in 1798 and considered to start the Romantic Movement era in English literature.

"The Thorn" is one of several poems by Wordsworth through which he suggests the supernatural. It also explores subjects such as the human psyche, the fallen woman of the late 18th century, and especially the reliability of narrator and reader's role in interpretation. On the surface, "The Thorn" speaks of a woman, Martha Ray, who, after giving "with a maiden's true good-will/Her company to Stephen Hill" (X, 106-108), discovers on what was to be their wedding day that Stephen is betrothed to another. Finding herself with a child, mad with anguish, she retreats to a mountaintop, where she spends most of her days. However, though supposedly pregnant, no child is ever seen. It is unknown if the child is stillborn or murdered by Martha's own hand. The consequence of the pregnancy, though, appears to be Martha's final descent into insanity, and 20 years later she can still be heard wailing, "Oh misery! oh misery! / Oh woe is me! Oh misery!" (VI: 65-66, VII: 76-77, XVIII: 194 and 200, XXII: 244-245).

Wordsworth may be suggesting to us that the beauteous heap is an infant's grave because in several parts of the poem (ex. V: 49-52 and VI: 60-61), he describes the hill "like" an infant's grave. Going to the spot when the woman is there described as a "dare" in the poem, this could be because she is sad and always weeping or she may be crazy, or because she in depression. A common question might come to mind when reading this poem; why does the woman go to the top of this mountain and weep? Well the author answers this with the best to his abilities by saying what he knows previously about this woman's life. This poem leaves us with a lot of unanswered questions, or answers that could be true, but the poem never really justifies if its suggestions are actually correct. Throughout the poem, we hear a lot of different opinions, and views on the woman. Questions that come to one's mind are: what does the thorn symbolize and how does it relate to this obviously sad woman?

While the subjects presented here-which include infanticide, a "fallen" woman, and insanity - are enticing to the modern reader, an even greater complexity can be found within the narrator's role. Here we find a man, a newcomer to the area 20 years after the jilting of Martha Ray, who attempts to tell us the story. However, it becomes increasingly clear that neither the narrator nor the rest of the townsfolk really knows what had happened to Martha Ray and her child - if, in fact, there even was a child in the first place.

"The Thorn" is a narrative poem containing elements such as a plot, characters, conflict and setting. It is a long poem that consists of (22) stanzas; each is made of (11) lines. It is also necessary to note that the poem was written in ballad form. The ballads are slow and that is why this poem also had to move slowly and naturally. Tautology, in this aspect, worked in the favour of the poem. Although, the duplication of words may make the written piece, it also helps poets stress upon the emotions and imagery they want to develop in the poem.

The poem itself is entitled "The Thorn" and it starts with the description of "this aged Thorn" that "stands erect" on the highest top of a mountain. Furthermore, the thorn symbolizes Martha's pain and misery as well as her dead child. 
AWEJ for translation \& Literacy Studies Volume, 1 Number 3, August 2017

The Use of Tautology in "The Thorn" by William Wordsworth

Al-Marsumi

The main theme of "The Thorn" is "Death" which overwhelms the whole atmosphere of the poem represented by the death of love, humanity, nature and hope. Other themes can also be found:

- Nature: this reflects the gloom and agony of the characters. The depressed mother and the dead baby become part of the gloomy, thorny landscape.

- Seclusion and isolation: next to the thorn, there is a little muddy pond and a mossy hill, "A beauteous heap" which is supposed to be the place where Martha's child was buried, as she used to go there and lament its death. The thorn is as isolated as Martha herself. She decided to lead a life of loneliness on the mountain.

- Melancholy: Martha was depressed, crazy and she was pregnant. Her cries of pain "'Oh misery! oh misery! / Oh woe is me! oh misery!" "are repeated throughout the poem. The "aged thorn" becomes Martha's only companion on the top of the mountain where she painfully cries.

- The supernatural power: there are also supernatural elements in the poem, like the stirring hill, the moss which is spotted with the infant's blood and the pond which mirrors the baby's face.

- Loss of innocence: as represented by the lost childhood. The scarlet colour is associated with adultery and murder. It refers to the loss of innocence or virginity and to adultery or lust. The woman's scarlet coat indicates that she is a sinner. She has to endure pain and torture that might finally purge her of her sins. She might be not only adulterous but also a murderer who killed her own baby in a moment of despair.

\section{Stylistic Analysis of the Poem}

\section{Lexical Level}

This category examines the tautological 'content word': nouns, verbs, adjectives and adverbs in the poem under study. Content words belong to 'open class' where new words can be added to the class as the need arises. The other class is known as 'closed class' including: prepositions, pronouns, particles, determiners, conjunctions, demonstratives and interjections. They are made up of finite sets of words which are never expanded. Leech (1982) specifies three tests to define English open classes. These tests are to define: Function, form and meaning. Appendix A shows the distribution of the tautological content words with the numbers of their occurrence in the poem.

Appendix A shows that the total number of the tautological content words in the poem under investigation is 120 . Nouns occupy the highest frequency of occurrence $(50,45.833 \%)$. The majority of the nouns used insure the fact mentioned above that Wordsworth is 'a poet of nature'. His deep love for the "beauteous forms" of the natural world is tautologically represented in this poem through repeating nouns reflecting nature like: the thorn $(16,29.090 \%)$, mountain $(11,20 \%)$, hill $(9,16.363 \%)$, pond $(9,16.363 \%)$, wind $(7,12.727 \%)$, rain $(6$, $10.909 \%)$, star $(4,7.272 \%)$ and ground $(4,7.272 \%)$. Some other nouns reflecting nature with less frequency are: leaves, stone, storm, winter, vale, water, air, colours, sky, etc. All tautological nouns are concrete $(49,98 \%)$ and only 'misery' $(1,2 \%) \quad$ is abstract. This reveals the high interest the poet has towards using natural characters.

In Appendix A, adjectives are tautologically shown with frequency of $(32,26.666 \%)$. Tautology is obvious in adjectives describing 'nature' like: beauteous (3, 9.677\%) in (VI: 37 beauteous heap), (V: 51 beauteous dyes) and (VI: 57 beauteous hill). He also describes 'air' as 
'frosty' $(2,6.451 \%)$ and 'keen (2, 6.451\%) in (VII: 74 and VIII: 85). The highest frequency of occurrence is for the adjective 'little' $(7,22.580 \%)$ describing images of nature like: pond in (III: 30 and XIX: 204) and breezes in (XVIII: 196). Wordsworth not only uses tautological adjectives for nature, but also premodifies the names and objects reflecting other themes found in the poem: death, misery, seclusion, melancholy, etc. A high tautological occurrence is for 'poor' $(6,19.354 \%)$ describing the 'thorn' in (II: 17 and 22), the woman in (VIII: 81 and XI: 118) and the child/infant in (XIV: 147 and XX: 213). Since the 'Thorn' symbolizes an 'imaginary infant' which proposes that the mosses are trying to "bury" the tree, as they are re-enacting the burial of the baby that may lie under the close by "hill of moss", Wordsworth tautologically uses different and alternative adjectives reflecting these images in: old (4, 12.903\%), aged (3, 9.677\%), overgrown $(3,9.677 \%)$, grey $(3,9.677 \%)$. A similar use of tautologies is in: scarlet $(3,9.677 \%)$, red $(2,6.45 \%)$ and, alternatively, he also uses 'vermilion' to personify the 'woman's misery', 'infant's death' and, consequently, the 'tragic destiny'.

Verbs are used tautologically with frequency of occurrence $(24,20 \%)$. Dynamic verbs have a frequency rate $(18,75 \%)$, while stative verbs $(6,25 \%)$. The highest rate of the dynamic verbs is due to the narration nature of the selected poem. The story implies a simple scheme of movement. Though tautological dynamic verbs are higher than stative ones, the highest rates of frequency are for the tautological verbs that are stative, for example: was $(18,75 \%)$, see $(8$, $33.333 \%)$, look $(7,29.166 \%)$, know $(5,20.833 \%)$, were $(4,16.666 \%)$, be $(3,12.5 \%)$ and wish (3, 12.5\%). This might be related to Wordsworth's deep interest in describing nature and subjects, and it can also be a justification for using 'present' tenses in parts of the poem depicting images and scenes the poet embodies to his readers; whereas 'past' tenses are used to narrate the story.

Within the expected level, few tautological adverbs come with the number and frequency rate $(9,7.5 \%)$. Appendix A shows that all the adverbs used are those expressing place and time of the events taken place in the poem.

At the lexical level, appendix A points out many examples of conceptual groups that are tautologically used: thorn, stone, leaves, pond, colours, stars, mountain, hill, bright, etc. are examples relating to 'nature and life'. Tautological words relating to 'despair and death' are like: misery, woe, wretched, overgrown, poor, scarlet, grave, burry, cry, etc. Other tautologies are those words relating to 'place': there, around, beyond and through; and those relating to 'time': years, time, day and night. There are some examples of tautological words relating to 'body': head, brain,

\section{Grammatical Level}

This level reveals types of sentences (clauses and phrases) tautologically used in the selected poem as illustrated in Appendix B. This is to focus on what Wordsworth is doing with the tautology of the poem and how he functions the grammatical devices to achieve the intended themes.

Russell (2005) states that it is not necessary that such repetition happens in the chorus, tautology is something that can be found out even in the middle of the stanzas. 
As shown in appendix B, (16) tautological sentences are used. Most of them $(13,81.25 \%)$ are of a declarative assertive type. This indicates that what Wordsworth tries to assert is true. The highest frequency of occurrence is that for the exclamative tautology of "Oh misery! oh misery!" $(10,62.5 \%)$ and "Oh woe is me! oh misery!" (3, 18.75\%). In fact, there are cases where repetition is more like the refrain and occupies the larger space in the stanzas. The poet insists on depicting images like: adultery, murder and misery which are juxtaposed to each other, so that feelings of frustration, bewilderment and suffering are produced and then focused on.

Reviewing the poem, it is evident that most of the tautological sentences used are parts of 'compound' ones, as in (I, 6): "It stands erect, and like a stone ..."; others are identified as parts of 'complex' sentences as in (II, 20):

"So close, you'd say that they are bent

With plain and manifest intent

To drag it to the ground;

And all have joined in one endeavour

To bury this poor Thorn for ever."

Furthermore, it is the specific form of Wordsworth's problemization that tautology is strengthened by every step taken to eliminate it, that raises assumptions regarding the repetition to be a condition of chances for modification as a master trope. Owing to this fact, William Wordsworth uses different words or phrases with the same meanings (i.e. redundancy) to make the way for even more virtual tautology. Appendix C shows such tautologies:

In sentences (17), the tautological verses reflect redundantly the truth that the 'thorn' tree, as an object in the landscape, becomes a representation of the essential mystery. Martha, as always, sits beside this 'thorn' that stands erect on the highest top of a mountain (as in 19), where she spends much of her time journeying to and sitting by the thorn at its mountain-top site, recalling her infant with a sense of agony, regret and suffering. This scene is more deeply depicted through the tautological verses used (in 21) that emphasize the hearing of Martha's desperate cries: "Oh misery! Oh misery! /Oh woe is me! Oh misery".

In sentences (18), Wordsworth redundantly emphasizes another fact that no one knows for sure how the prevailing crime is achieved since all what is said are rumors. The hopeless mother may unconsciously kill her baby (in 22) or hang it or drown it in the pond. Such redundant verses are related to another dispute (in 20) where people do not know if her child was born dead or alive, or whether miscarriage or abortion occurred. Nevertheless, the poet (in 23) affirms a fact that the baby's face can be seen plainly, looking at you whenever you look on it. In fact, Wordsworth has successfully used tautology to convey the intended themes of his poem.

\section{Tense}

Appendix B shows that all tautological sentences have 'simple finite' verb phrases. The only 'simple non- finite' is the following:

- To drag it to the ground; (II, 20 and XXII, 238)

As mentioned earlier, the whole poem is written in 'present' tense to convey the beautiful imaginary ideas through selected natural objects that electrify the imagination of the poet. 
Wordsworth shifts the tense into 'past' when narrating the tale, though no many dramatic actions transpire during the occasion. In this sense, the poem conforms to Wordsworth's idea of poetry as passion in that the poem, as a dramatic exchange between two characters, enacts a kind of "history or science of feelings" linguistically.

\section{Foregrounding}

Foregrounding is the violation of the scheme used to surprise or impress readers. It can be realized by 'deviation' and 'parallelism'. Investigating the selected poem thoroughly, only grammatical, morphological and graphological deviation of the tautological sentences listed in appendixes $\mathrm{A}$ and $\mathrm{B}$ can be analyzed linguistically:

\section{Grammatical Deviation}

Many of such deviations are used in the selected poem; some are used tautologically in the sentences in appendix A and B. The poet sometimes transfers verbs in subject positions when sentences are not interrogatives or even in the bottom of the stanzas which may indicate that he focuses on actions rather than subjects:

- With lichens is it overgrown. (I: 10)

- And why sits she beside the Thorn (VIII: 82)

- "More know I not, I wish I did, (VIX: 145)

- For many a time and oft were heard

Cries coming from the mountain head: (XV: 160-161)

Wordsworth also deviates when placing adverbial and prepositional phrases:

- And to herself she cries, (VI:64)

- For the true reason no one knows: (IX:91)

- This wretched Woman thither goes; (VII:68)

- She to the mountain-top would go, (XII:125)

Furthermore, two examples have elliptical subjects:

- As like as like can be: (V:53)

- And there sitsin a scarlet cloak, (XVI:169)

\section{Morphological Deviation}

The poet uses deviated forms like: 'twas (XIV:151), oft (XV:160), o'ergrown (II:12), babe (XIX:210, XXI:232), whene'er (XX:221) and 'tis (XX:221). Deviant morphology is used as an element of the poetic technique. Wordsworth's art can be enhanced if his readers could understand the machinery behind using such deviation.

\section{Graphological Deviation}

Graphological forms, like: spelling, italicization, capitalization and hyphenation are expressive when they are a writer's choice. Discarding the rules of writing as to form creative language, Wordsworth deviates from the norms in most parts of the poem to attract the attention of his readers. In appendix A and (2), many of the tautological sentences end with commas which may reflect the sense of wandering, though, they are placed in the bottom in these verses:

- And there she sits, until the moon (XVIII:194)

- She shudders, and you hear her cry, (XVIII:199)

$-$ 
AWEJ for translation \& Literacy Studies Volume, 1 Number 3, August 2017

The semi-colons at the end of some verses are used to indicate end stopped lines and may stress that the decision is being made strictly, as in the following examples:

- To drag it to the ground; (II:20)

- I cannot tell; (IX:90)

- wind that blows; (VII:70)

- No mortal ever knew; (XIV:148)

- No earthly tongue could ever tell; (XIV:150)

In other examples, the colon is used to make a very pointed pause between two thoughts:

- As like as like can be: (V:53)

- For the true reason, no one knows: (IX:91)

- Cries coming from the mountain head: (XV:161)

The poet deviates when using the hyphen in the bottom of some examples to reflect a short pause and to express that the thought will be completed:

- "There is a Thorn-it looks so old, (I:1)

- Nay_if a child to her was born (XIV:149)

Though capitalization at the beginning of verses is a characteristic of poetic style, Wordsworth capitalizes certain words used in the tautological sentences, like: Babe (XIX:210, XXI:232) and Woman (VI:63, VII:68, VIII:81, X:102 and XVII:188) to express that they are the central issues in the poem.

\section{Conclusion}

William Wordsworth has used tautology in his poem "The Thorn", not to fill out the space but to strengthen the feeling of the words. The implicit licensing of a supposed language substance over the notwithstanding form affirms that there are various reasons why tautology and repetition are used frequently in Wordsworth poem. Tautology is not only a mindless repetition of words but it is an expression of the depth of the human feelings.

Different stages of the arguments regarding the use of tautology in "The Thorn" may form a dialectal pattern. Firstly, tautology is illustrated as a certainty linked with the operation of meaning in language of the poem. Secondly, it is also seen as the externality and finally, it is reassimilated into the concluding thesis as an important aspect of the particular content to which it was thought be an external. In fact, the poem is not that of making a decision but it is the art of indecision. following:

Depending on the stylistic analysis based on Leech's model (1969), the results show the

- At the lexical level, content words (120) are tautologically investigated to show higher frequency of occurrence of nouns $(50,45.833 \%)$ than verbs $(24,20 \%)$, adjectives $(32,26.666 \%)$ or adverbs $(9,7.5 \%)$. As a poet of nature, Wordsworth has deep interest in describing natural subjects and that is why concrete nouns occur with a higher frequency $(49,98 \%)$ than abstract nouns $(1,2 \%)$. On the other hand, Tautology is used to describe conceptual groups relating to 'nature and life', 'despair and death', 'place', 'time' and 'body'. 
- At the grammatical level, tautology is analyzed in sentences (16 clauses and phrases) where there is repetition of the same words. The highest frequency of occurrence is that of the declarative type $(13,81.25 \%)$ and only two sentences $(3,18.75 \%)$ are exclamative. Most of these sentences are formed as parts of compound ones. On the other hand, the analysis reveals another type of tautology, i.e. 'redundancy' where different words or phrases are used to express the same meanings. Wordsworth has successfully used tautology to achieve the themes includes in his poem: nature, melancholy, seclusion and isolation, supernatural power and loss of innocence. Tenses of the tautological sentences are almost present as they are used to describe the different views of the natural landscapes but the poet shifts towards using the past tense when narrating the events in the poem.

- Deviation as a type of foregrounding is analyzed grammatically, morphologically and graphologically. As an attempt to attract his readers and emphasize some thoughts, Wordsworth deliberately deviates from the rules of grammar when placing verbs in subject positions, using elliptical subjects and misplacing adverbial and prepositional phrases. He also uses his poetic technique in the deviation of particular forms of words. Furthermore, he discards some rules of punctuation, using or misusing commas, colons, semi-colons, capitalization and hyphenation as to make his style more creative and expressive.

\section{About the Author:}

Nawar Hussein Rdhaiwi Al-Marsumi MA holder and a university instructor at Baghdad University-College of Languages, the English Department. Her specific specialization is linguistics and contrastive Studies. She has published papers in contrastive studies, pragmatics and stylistics.

\section{References}

Bradford, R. (1997). Stylistics . London: Routledge.

Bulhof, J. \& S. Gimbel (2001). “Deep Tautologies”. Pragmatics \& Cognition 9, 279-292.

Cherry, C. (1978). On Human Communication. 3rd edition. Cambridge, MA: MIT.

Gibbs, R. W. (1994). The Poetics of Mind: Figurative thought, language, and understanding, Cambridge: Cambridge University Press.

Eliot, T. S. (2003). A Study Guide for T.S. Eliot's "The Hollow Men". USA: Chelsea House Publishers.

Jakobson, R. (1960). Essays in General Linguistics. Style in Language, T.A. Sebeok, ed Cambridge, Mass.: MIT Press.

Jespersen, O. (1917). Negation in English and Other Languages. Kobenhavn: Host.

Keach, W. (2004). Arbitrary Power: Romanticism, Language, Politics. Princeton: Princeton University Press.

Leech, G. (1969). A Linguistic Guide to English Poetry. London: Longman.

Leech, G. \& M.H. Short. (1981). Style in Fiction: London: Longman.

Leech, G \& R. Garside. (1982). Grammatical Tagging of the LOB Corpus: general survey. In Johansson, S. \& Hofland K. Eds., 1, 66-81.

Matthews, P.H. (2014). The Concise Oxford Dictionary of Linguistics. Oxford: Oxford University Press.

Merriam-Webster's Dictionary of Synonyms. (1984). USA: Merriam-Webster Incorporated. 
Mitchell, T. F. (2013). Syntagmatic Relations in Linguistic Analysis. Wiley Online Library. http://onlinelibrary.wiley.com/doi/10.1111/j.1467-968X.1958.tb01274.x/full

Moore, M. (2001) A Review of General Semantics. Languages and linguistics. https://scholar.google.com/scholar?q=Moore,+M.+(2001)+A+Review+of+General+Sema ntics.+Languages+and+linguistics.\&hl=en\&as_sdt=0\&as_vis=1\&oi=scholart\&sa=X\&ve $\mathrm{d}=$ 0ahUKEwjrtM3axfPUAhXC2xoKHey-CmsQgQMIJDAA

Patra, K. P. \& A. N. Prasad (2006). Recritiquing William Wordsworth. India: Sarup \& Sons.

Pomorska, K. al. (Ed.). (1987). Language, Poetry and Poetics. Amsterdam: Mouton.

Russell, C. (2005). A Defense of Tautology: Repetition and Difference' in Wordsworth's Note to 'The Thorn'. EBSCOhost Connection online, 28 (2), 104.

http://connection.ebscohost.com/c/articles/18954595/defence-tautology-repetitiondifference-wordsworths-note-thorn

Sarker, S.K. (2003). A Companion to William Wordsworth. Atlantic Publishers \& Dist.

Shakespeare, W. (2002). Hamlet.UK: Wordsworth Editions Limited.

Short, M. (1996). Exploring the Language of Poems, Plays and Prose. London: Longman.

Side, J. (2006). Wordsworth's Empiricist Poetic and its Influence in the Twentieth Century, PhD thesis, University of Leeds, UK. http://etheses.whiterose.ac.uk/1041/3/main_thesis.pdf

Simpson J. A. \& E. S. C. Weiner (1998). The Oxford English Dictionary. Oxford: Oxford University Press

Simpson, P. (2007). Stylistics. London: Rutledge.

States, B.0. (1998). Of Paradoxes and Tautologies. The American Scholar 67, 51-66. http://www.jstor.org/discover/10.2307/41212715?uid=3739368\&uid=2\&uid=4\&sid=21102 643851907

Stevenson A. (2010). Oxford Dictionary of English. New York: Oxford University Press.

Stevenson A. \& M. Waite (2011). Concise Oxford English Dictionary. New York: Oxford University Press.

Thornborrow, J. \& S. Wareing, (1998). Patterns in Language: An Introduction to Language and Literary Style. London: Routledge.

Verdonk, P. (2002). Stylistics. Oxford: Oxford University Press.

Waldoff, L. (2001). Wordsworth in His Major Lyrics: The Art and Psychology of SelfRepresentation. Colombia: Missouri Press University.

Ward, G. L. \& J. Hirschberg, (1991). A Pragmatic Analysis of Tautological Utterances. Journal of Pragmatics, 15, 507-520.

Wierzbicka, A. (1987). Boys will be Boys: 'radical semantics' vs. 'radical pragmatics'.' Language 63 (1), 95-114.

Appendix A: Frequencies of Occurrence of the Tautological Content Words in "The Thorn" Poem

\begin{tabular}{|c|c|c|c|c|c|c|c|c|c|c|c|}
\hline Noun & \multicolumn{2}{|c|}{$\begin{array}{l}\text { No. of } \\
\text { Occurrence } \\
\%\end{array}$} & Verb & \multicolumn{2}{|c|}{$\begin{array}{l}\text { No. of } \\
\text { Occurrence } \\
\%\end{array}$} & \multirow{2}{*}{$\begin{array}{l}\text { Adjective } \\
\text { old }\end{array}$} & \multicolumn{2}{|c|}{$\begin{array}{l}\text { No. of } \\
\text { Occurrence } \\
\%\end{array}$} & \multirow{2}{*}{$\begin{array}{l}\text { Adverb } \\
\text { through }\end{array}$} & \multicolumn{2}{|c|}{$\begin{array}{l}\text { No. of } \\
\text { Occurrence } \\
\%\end{array}$} \\
\hline Thorn & 16 & $\begin{array}{l}29.09 \\
0\end{array}$ & look & 7 & $\begin{array}{l}29.16 \\
6\end{array}$ & & 4 & 12.5 & & 3 & 3.333 \\
\hline Years & 2 & 3.636 & say & 7 & $\begin{array}{l}29.16 \\
6\end{array}$ & high & 5 & 15.625 & beyond & 2 & 22.222 \\
\hline
\end{tabular}

Arab World English Journal for Translation \& Literary Studies eISSN: 2550-1542 | www.awej-tls.org 
AWEJ for translation \& Literacy Studies Volume, 1 Number 3, August 2017

The Use of Tautology in "The Thorn" by William Wordsworth

Al-Marsumi

\begin{tabular}{|c|c|c|c|c|c|c|c|c|c|c|c|}
\hline Child & 5 & 9.090 & $\mathrm{Be}$ & 3 & 12.5 & grey & 3 & 9.375 & there & 13 & $\begin{array}{l}144.44 \\
4\end{array}$ \\
\hline Leaves & 2 & 3.636 & stand & 2 & 8.333 & sad & 3 & 9.375 & where & 2 & 22.222 \\
\hline Stone & 2 & 3.636 & was & 18 & 75 & erect & 2 & 6.25 & $\begin{array}{l}\text { wherefo } \\
\text { re }\end{array}$ & 4 & 44.444 \\
\hline lichens & 2 & 3.636 & bury & 3 & 12.5 & aged & 3 & 9.375 & when & 3 & 33.333 \\
\hline Top & 4 & 7.272 & see & 8 & $\begin{array}{l}33.33 \\
3\end{array}$ & wretched & 2 & 6.25 & again & 2 & 22.222 \\
\hline mountain & 11 & 20 & seek & 2 & 8.333 & overgrown & 3 & 9.375 & around & 2 & 22.222 \\
\hline Storm & 2 & 3.636 & were & 4 & $\begin{array}{l}16.66 \\
6\end{array}$ & heavy & 2 & 6.25 & beneath & 2 & 22.222 \\
\hline Rain & 6 & $\begin{array}{l}10.90 \\
9\end{array}$ & Sit & 5 & $\begin{array}{l}20.83 \\
3\end{array}$ & frosty & 2 & 6.25 & & & \\
\hline Winter & 2 & 3.636 & speak & 2 & 8.333 & little & 7 & 21.875 & & & \\
\hline Vale & 2 & 3.636 & Cry & 3 & 12.5 & close & 3 & 9.375 & & & \\
\hline Yards & 3 & 5.454 & Go & 9 & 37.5 & fresh & 2 & 6.25 & & & \\
\hline Path & 2 & 3.636 & know & 5 & $\begin{array}{l}20.83 \\
3\end{array}$ & lovely & 3 & 9.375 & & & \\
\hline Pond & 9 & $\begin{array}{l}16.36 \\
3\end{array}$ & blow & 2 & 8.333 & beauteous & 3 & 9.375 & & & \\
\hline Water & 2 & 3.636 & tell & 5 & $\begin{array}{l}20.83 \\
3\end{array}$ & fair & 4 & 12.5 & & & \\
\hline Air & 3 & 5.454 & wish & 3 & 12.5 & green & 3 & 9.375 & & & \\
\hline Heap & 3 & 5.454 & view & 2 & 8.333 & scarlet & 3 & 9.375 & & & \\
\hline hill & 9 & $\begin{array}{l}16.36 \\
3 \\
\end{array}$ & sworn & 3 & 12.5 & bright & 3 & 9.375 & & & \\
\hline colours & 2 & 3.636 & Do & 2 & 8.333 & red & 2 & 6.25 & & & \\
\hline Eye & 3 & 5.454 & Climb & 2 & 8.333 & blue & 3 & 9.375 & & & \\
\hline Dye & 2 & 3.636 & came & 2 & 8.333 & clear & 3 & 9.375 & & & \\
\hline Cloak & 2 & 3.636 & saw & 2 & 8.333 & keen & 2 & 6.25 & & & \\
\hline Star & 4 & 7.272 & stir & 2 & 8.333 & poor & 6 & 18.75 & & & \\
\hline Earth & 3 & 5.454 & & & & true & 2 & 6.25 & & & \\
\hline Infant & 8 & $\begin{array}{l}14.54 \\
5\end{array}$ & & & & plain & 4 & 12.5 & & & \\
\hline Grave & 4 & 7.272 & & & & kindled & 2 & 6.25 & & & \\
\hline Size & 2 & 3.636 & & & & last & 2 & 6.25 & & & \\
\hline Time & 7 & $\begin{array}{l}12.72 \\
7\end{array}$ & & & & born & 4 & 12.5 & & & \\
\hline woman & 5 & 9.090 & & & & jutting & 2 & 6.25 & & & \\
\hline Misery & 23 & $\begin{array}{l}41.81 \\
8\end{array}$ & & & & full & 5 & 15.625 & & & \\
\hline Day & 8 & $\begin{array}{l}14.54 \\
5 \\
\end{array}$ & & & & & & & & & \\
\hline Night & 3 & 5.454 & & & & & & & & & \\
\hline Wind & 7 & 12.72 & & & & & & & & & \\
\hline
\end{tabular}

Arab World English Journal for Translation \& Literary Studies

eISSN: 2550-1542 | www.awej-tls.org 
AWEJ for translation \& Literacy Studies Volume, 1 Number 3, August 2017

The Use of Tautology in "The Thorn” by William Wordsworth

Al-Marsumi

\begin{tabular}{|c|c|c|c|c|c|c|c|c|c|}
\hline & & 7 & & & & & & & \\
\hline Sky & 2 & 3.636 & & & & & & & \\
\hline Cry & 5 & 9.090 & & & & & & & \\
\hline Spot & 4 & 7.272 & & & & & & & \\
\hline Name & 2 & 3.636 & & & & & & & \\
\hline Martha & 5 & 9.090 & & & & & & & \\
\hline Maid & 2 & 3.636 & & & & & & & \\
\hline Stephen & 2 & 3.636 & & & & & & & \\
\hline Oath & 2 & 3.636 & & & & & & & \\
\hline church & 2 & 3.636 & & & & & & & \\
\hline Woe & 3 & 5.454 & & & & & & & \\
\hline Senses & 2 & 3.636 & & & & & & & \\
\hline Case & 2 & 3.636 & & & & & & & \\
\hline Brain & 2 & 3.636 & & & & & & & \\
\hline Head & 2 & 3.636 & & & & & & & \\
\hline Voices & 2 & 3.636 & & & & & & & \\
\hline Crag & 3 & 5.454 & & & & & & & \\
\hline ground & 4 & 7.272 & & & & & & & \\
\hline Face & 3 & 5.454 & & & & & & & \\
\hline Breeze & 2 & 3.636 & & & & & & & \\
\hline Baby & 7 & $\begin{array}{l}12.72 \\
7\end{array}$ & & & & & & & \\
\hline Tufts & 2 & 3.636 & & & & & & & \\
\hline \multicolumn{10}{|c|}{ Total No. of tautological content words: 120} \\
\hline No. & \multicolumn{2}{|c|}{ Ratio } & No. & Ratio & No. & Ratio & No. & Ratio & \\
\hline 55 & \multicolumn{2}{|c|}{$45.833 \%$} & 24 & $20 \%$ & 32 & $26.666 \%$ & 9 & $7.5 \%$ & \\
\hline
\end{tabular}

Appendix B: Frequencies of Occurrence of the Tautological Sentences in "The Thorn" Poem

\begin{tabular}{|l|l|l|l|l|}
\hline No. & Clauses and Phrases & Types & $\begin{array}{r}\text { No. of } \\
\text { Occurrence }\end{array}$ & \\
\hline 1 & It looks so old & Declarative & 2 & 12.5 \\
\hline 2 & It stands erect, & Declarative & 2 & 12.5 \\
\hline 3 & (it is/is it) overgrown & Declarative & 2 & 12.5 \\
\hline 4 & To drag it to the ground & Declarative & 2 & 12.5 \\
\hline 5 & like an infant's grave in size & Declarative & 2 & 12.5 \\
\hline 6 & And to herself she cries & Declarative & 2 & 12.5 \\
\hline 7 & Oh misery! oh misery! & Exclamative & 10 & 62.5 \\
\hline 8 & Oh, woe is me! oh misery! & Exclamative & 3 & 18.75 \\
\hline 9 & When the blue daylight's in the skies & Interrogative & 2 & 12.5 \\
\hline 10 & And when the whirlwinds on the hill & Declarative & 2 & 12.5 \\
\hline 11 & Or frosty air is keen and still & Declarative & 2 & 12.5 \\
\hline 12 & Beneath that hill of moss so fair & Declarative & 2 & 12.5 \\
\hline 13 & As like as like can be & Declarative & 2 & 12.5 \\
\hline 14 & I cannot tell & Declarative & 3 & 18.75 \\
\hline
\end{tabular}

Arab World English Journal for Translation \& Literary Studies eISSN: 2550-1542 | www.awej-tls.org 
AWEJ for translation \& Literacy Studies Volume, 1 Number 3, August 2017

The Use of Tautology in "The Thorn” by William Wordsworth

Al-Marsumi

\begin{tabular}{|l|l|l|l|l|}
\hline 15 & The little Babe (lies/was) buried there & Declarative & 2 & 12.5 \\
\hline 16 & wind (that/may) blow(s) & Declarative & 2 & 12.5 \\
\hline
\end{tabular}

Appendix C: Tautological Sentences used as "Redundancy" in "The Thorn" Poem

\begin{tabular}{|c|c|c|c|}
\hline No. & Redundant Sentences & No. of Stanza & No. of Line \\
\hline 17. & $\begin{array}{l}\text { - And there, beside the Thorn, she sits } \\
\text { - And why sits she beside the Thorn, } \\
\text { - The Thorn which I described to you, } \\
\text { And there sits in a scarlet cloak, } \\
\text { And there she sits, until the moon }\end{array}$ & $\begin{array}{l}\text { VII } \\
\text { VIII } \\
\text { XVI } \\
\text { XVIII }\end{array}$ & $\begin{array}{l}71 \\
82 \\
169-170 \\
194\end{array}$ \\
\hline 18. & $\begin{array}{l}\text { - For the true reason, no one knows: } \\
\text { - "More know I not, I wish I did, } \\
\text { - No mortal ever knew; } \\
\text { - No earthly tongue could ever tell; }\end{array}$ & $\begin{array}{l}\text { IX } \\
\text { XIV } \\
\text { XIV } \\
\text { XIV }\end{array}$ & $\begin{array}{l}91 \\
145 \\
148 \\
150\end{array}$ \\
\hline 19. & $\begin{array}{l}\text { - This wret Review of ched Woman thither goes; } \\
\text { - Thus, to the dreary mountain-top } \\
\text { Does this poor Woman go? } \\
\text { "But wherefore to the mountain-top } \\
\text { Can this unhappy Woman go, } \\
\text { She to the mountain-top would go, } \\
\text { When she was on the mountain high, }\end{array}$ & $\begin{array}{l}\text { VII } \\
\text { VIII } \\
\text { X } \\
\text { XII } \\
\text { XXII }\end{array}$ & $\begin{array}{l}69 \\
80-81 \\
101 \\
125 \\
240 \\
\end{array}$ \\
\hline 20. & $\begin{array}{l}\text { - Held that the unborn infant wrought } \\
\text { - Nay-if a child to her was born } \\
\text { - And if 'twas born alive or dead, }\end{array}$ & $\begin{array}{l}\text { XIII } \\
\text { XIV } \\
\text { XIV }\end{array}$ & $\begin{array}{l}140 \\
149 \\
151\end{array}$ \\
\hline 21. & $\begin{array}{l}\text { - For many a time and oft were heard } \\
\text { Cries coming from the mountain head: } \\
\text { I turned about and heard her cry, } \\
\text { She shudders, and you hear her cry, } \\
\text { That I have heard her cry, }\end{array}$ & $\begin{array}{l}\text { XV } \\
\text { XVIII } \\
\text { XVIII } \\
\text { XXII }\end{array}$ & $\begin{array}{l}160-161 \\
192 \\
199 \\
243\end{array}$ \\
\hline 22. & $\begin{array}{l}\text { She hanged her baby on the tree; } \\
\text { Some say she drowned it in the pond, } \\
\text { But kill a new-born infant thus, } \\
\text { I do not think she could! }\end{array}$ & $\begin{array}{l}\text { XIX } \\
\text { XX }\end{array}$ & $\begin{array}{l}206-207 \\
214-215\end{array}$ \\
\hline 23. & $\begin{array}{l}\text { A baby and a baby's face, } \\
\text { And that it looks at you; } \\
\text { Whene'er you look on it, 'tis plain } \\
\text { The baby looks at you again. }\end{array}$ & $\begin{array}{l}\mathrm{XX} \\
\mathrm{XX}\end{array}$ & $\begin{array}{l}219-220 \\
212-222\end{array}$ \\
\hline
\end{tabular}

Appendix D: The Thorn (1798) BY WILLIAM WORDSWORTH

I

"There is a Thorn-it looks so old,

In truth, you'd find it hard to say

Arab World English Journal for Translation \& Literary Studies 
How it could ever have been young,

It looks so old and grey.

Not higher than a two years' child

It stands erect, this aged Thorn;

No leaves it has, no prickly points;

It is a mass of knotted joints,

A wretched thing forlorn.

It stands erect, and like a stone

With lichens is it overgrown.

II

"Like rock or stone, it is o'ergrown,

With lichens to the very top,

And hung with heavy tufts of moss,

A melancholy crop:

Up from the earth these mosses creep,

And this poor Thorn they clasp it round

So close, you'd say that they are bent

With plain and manifest intent

To drag it to the ground;

And all have joined in one endeavour

To bury this poor Thorn forever.

III

"High on a mountain's highest ridge,

Where oft the stormy winter gale

Cuts like a scythe, while through the clouds

It sweeps from vale to vale,

Not five yards from the mountain path,

This Thorn you on your left espy;

And to the left, three yards beyond,

You see a little muddy pond

Of water-never dry

Though but of compass small, and bare

To thirsty suns and parching air.

IV

"And, close beside this aged Thorn,

There is a fresh and lovely sight,

A beauteous heap, a hill of moss,

Just half a foot in height.

All lovely colours there you see,

All colours that were ever seen;

And mossy network too is there,

As if by hand of lady fair

The work had woven been;

And cups, the darlings of the eye,

So deep is their vermilion dye.

$\mathrm{V}$

"Ah me! what lovely tints are there

Of olive green and scarlet bright,

In spikes, in branches, and in stars,

Green, red, and pearly white!

This heap of earth o'ergrown with moss,

Which close beside the Thorn you see,

So fresh in all its beauteous dyes,

Is like an infant's grave in size,

As like as like can be: 
But never, never anywhere,

An infant's grave was half so fair.

VI

"Now would you see this aged Thorn,

This pond, and beauteous hill of moss,

You must take care and choose your time

The mountain when to cross.

For oft there sits between the heap,

So, like an infant's grave in size,

And that same pond of which I spoke,

A Woman in a scarlet cloak,

And to herself she cries,

'Oh misery! oh misery!

Oh, woe is me! oh misery!'

VII

"At all times of the day and night

This wretched Woman thither goes;

And she is known to every star,

And every wind that blows;

And there, beside the Thorn, she sits

When the blue daylight's in the skies,

And when the whirlwind's on the hill,

Or frosty air is keen and still,

And to herself she cries,

'Oh misery! oh misery!

Oh woe is me! oh misery!" "

VIII

"Now wherefore, thus, by day and night, In rain, in tempest, and in snow,

Thus to the dreary mountain-top

Does this poor Woman go?

And why sits she beside the Thorn

When the blue daylight's in the sky

Or when the whirlwind's on the hill,

Or frosty air is keen and still,

And wherefore does she cry?

$\mathrm{O}$ wherefore? wherefore? tell me why

Does she repeat that doleful cry?"

IX

"I cannot tell; I wish I could;

For the true reason no one knows:

But would you gladly view the spot,

The spot to which she goes;

The hillock like an infant's grave,

The pond - and Thorn, so old and grey;

Pass by her door-'tis seldom shut-

And if you see her in her hut-

Then to the spot away!

I never heard of such as dare

Approach the spot when she is there."

$\mathrm{X}$

"But wherefore to the mountain-top

Can this unhappy Woman go,

Whatever star is in the skies,

Whatever wind may blow?" 
"Full twenty years are past and gone

Since she (her name is Martha Ray)

Gave with a maiden's true good-will

Her company to Stephen Hill;

And she was blithe and gay,

While friends and kindred all approved

Of him whom tenderly she loved.

XI

"And they had fixed the wedding day,

The morning that must wed them both;

But Stephen to another Maid

Had sworn another oath;

And, with this other Maid, to church

Unthinking Stephen went-

Poor Martha! on that woeful day

A pang of pitiless dismay

Into her soul was sent;

A fire was kindled in her breast,

Which might not burn itself to rest.

XII

"They say, full six months after this,

While yet the summer leaves were green,

She to the mountain-top would go,

And there was often seen.

What could she seek? - or wish to hide?

Her state to any eye was plain;

She was with child, and she was mad;

Yet often was she sober sad

From her exceeding pain.

O guilty Father-would that death

Had saved him from that breach of faith!

\section{XIII}

"Sad case for such a brain to hold

Communion with a stirring child!

Sad case, as you may think, for one

Who had a brain so wild!

Last Christmas-eve we talked of this,

And grey-haired Wilfred of the glen

Held that the unborn infant wrought

About its mother's heart, and brought

Her senses back again:

And, when at last her time drew near,

Her looks were calm, her senses clear.

XIV

"More know I not, I wish I did,

And it should all be told to you;

For what became of this poor child

No mortal ever knew;

Nay_-if a child to her was born

No earthly tongue could ever tell;

And if 'twas born alive or dead,

Far less could this with proof be said;

But some remember well,

That Martha Ray about this time

Would up the mountain often climb. 
XV

"And all that winter, when at night

The wind blew from the mountain-peak,

'Twas worth your while, though in the dark, The churchyard path to seek:

For many a time and oft were heard

Cries coming from the mountain head:

Some plainly living voices were;

And others, I've heard many swear,

Were voices of the dead:

I cannot think, whate'er they say,

They had to do with Martha Ray.

XVI

"But that she goes to this old Thorn,

The Thorn which I described to you,

And there sits in a scarlet cloak,

I will be sworn is true.

For one day with my telescope,

To view the ocean wide and bright,

When to this country first I came,

Ere I had heard of Martha's name,

I climbed the mountain's height:-

A storm came on, and I could see

No object higher than my knee.

\section{XVII}

" 'Twas mist and rain, and storm and rain:

No screen, no fence could I discover;

And then the wind! in sooth, it was

A wind full ten times over.

I looked around, I thought I saw

A jutting crag,- - and off I ran,

Head-foremost, through the driving rain,

The shelter of the crag to gain;

And, as I am a man,

Instead of jutting crag, I found

A Woman seated on the ground.

$$
\text { XVIII }
$$

"I did not speak-I saw her face;

Her face!- - it was enough for me;

I turned about and heard her cry,

'Oh misery! oh misery!'

And there she sits, until the moon

Through half the clear blue sky will go;

And when the little breezes make

The waters of the pond to shake,

As all the country know,

She shudders, and you hear her cry,

'Oh misery! oh misery!',

"But what's the Thorn? and what the pond?

And what the hill of moss to her?

And what the creeping breeze that comes

The little pond to stir?"

"I cannot tell; but some will say

She hanged her baby on the tree; 
Some say she drowned it in the pond,

Which is a little step beyond:

But all and each agree,

The little Babe was buried there,

Beneath that hill of moss so fair.

$\mathrm{XX}$

"I've heard, the moss is spotted red

With drops of that poor infant's blood;

But kill a new-born infant thus,

I do not think she could!

Some say, if to the pond you go,

And fix on it a steady view,

The shadow of a babe you trace,

A baby and a baby's face,

And that it looks at you;

Whene'er you look on it, 'tis plain

The baby looks at you again.

\section{XXI}

"And some had sworn an oath that she

Should be to public justice brought;

And for the little infant's bones

With spades they would have sought.

But instantly the hill of moss

Before their eyes began to stir!

And, for full fifty yards around,

The grass-it shook upon the ground!

Yet all do still aver

The little Babe lies buried there,

Beneath that hill of moss so fair.

\section{XXII}

"I cannot tell how this may be,

But plain it is the Thorn is bound

With heavy tufts of moss that strive

To drag it to the ground;

And this I know, full many a time,

When she was on the mountain high,

By day, and in the silent night,

When all the stars shone clear and bright,

That I have heard her cry,

'Oh misery! oh misery!

Oh woe is me! oh misery!" " 